\title{
Effect of the sphingosine-1-phosphate receptor modulator ozanimod on leukocyte subtypes in relapsing MS
}

Sarah Harris, PhD, Jonathan Q. Tran, PharmD, Harry Southworth, PhD, MSc, Collin M. Spencer, BS, Bruce A.C. Cree, MD, PhD, MAS, and Scott S. Zamvil, MD, PhD

Neurol Neuroimmunol Neuroinflamm 2020;7:e839. doi:10.1212/NXI.0000000000000839

\section{Abstract}

\section{Objective}

To better understand ozanimod's mechanism of action (MOA), we conducted exploratory analyses from a phase 1 study to characterize ozanimod's effect on circulating leukocyte subsets in patients with relapsing multiple sclerosis.

\section{Methods}

An open-label pharmacodynamic study randomized patients to oral ozanimod hydrochloride $(\mathrm{HCl}) 0.5(\mathrm{n}=13)$ or $1 \mathrm{mg} / \mathrm{d}(\mathrm{n}=11)$ for $\sim 12$ weeks (including 7 -day dose escalation). Circulating leukocyte subsets were quantified using flow cytometry (days 28, 56, and 85) and epigenetic cell counting (days 2, 5, 28, 56, and 85) and compared with baseline (day 1) using descriptive statistics.

\section{Results}

Ozanimod caused dose-dependent reductions in absolute lymphocyte counts. Observed by both methodologies, circulating $\mathrm{CD}_{1} 9^{+} \mathrm{B}$ - and $\mathrm{CD}^{+} \mathrm{T}$-cell counts were reduced by $>50 \%$ with ozanimod $\mathrm{HCl} 0.5 \mathrm{mg}$ and $>75 \%$ with $1 \mathrm{mg}$ at day 85 . Based on flow cytometry, ozanimod $\mathrm{HCl}$ $1 \mathrm{mg}$ showed greater decreases in $\mathrm{CD}^{+}$than $\mathrm{CD}^{+} \mathrm{T}$ cells, greater decreases in both $\mathrm{CD} 4^{+}$and $\mathrm{CD}^{+}$central memory vs effector memory $\mathrm{T}$ cells, and reductions in mean $\mathrm{CD} 4^{+}$and $\mathrm{CD} 8^{+}$naive $\mathrm{T}$ cells by $\geq 90 \%$ at day 85 . In the flow cytometry analysis, changes in monocytes, natural killer, and natural killer $\mathrm{T}$ cells were minimal. Using epigenetic cell counting, greater reductions for Th17 than $\mathrm{T}$ regulatory cells were determined.

\section{Conclusion}

Ozanimod induced dose-dependent reductions in circulating B- and T-cell counts and differential effects on naive and memory $\mathrm{CD}^{+}$and $\mathrm{CD}^{+} \mathrm{T}$ cells and $\mathrm{CD} 19^{+} \mathrm{B}$ cells. Data characterized with both a novel epigenetic cell-counting method and flow cytometry support ozanimod's MOA.

\section{Clinical trial registration: clinicaltrials.gov NCT02797015.}

\author{
Correspondence \\ Dr. Harris \\ sarah.harris@bms.com
}




\section{Glossary}

ALC = absolute lymphocyte count $\mathbf{H C l}=$ hydrochloride; $\mathbf{N K}=$ natural killer; $\mathbf{M O A}=$ mechanism of action; $\mathbf{R M S}=$ relapsing MS; S1P = sphingosine-1-phosphate; SLO = secondary lymphoid organ; TEMRA = terminally differentiated effector T cells expressing CD45RA; VZV = varicella-zoster virus.

Ozanimod, a sphingosine-1-phosphate (S1P) receptor 1 and 5 modulator, is approved in the United States for the treatment of adults with relapsing forms of multiple sclerosis (MS) and in Europe for the treatment of adults with relapsingremitting MS. Ozanimod was effective and well tolerated in phase $2^{1,2}$ and phase 3 clinical trials of relapsing MS (RMS)., The mechanism by which ozanimod exerts therapeutic effects in MS is unknown but may involve reduced lymphocyte migration into the CNS. ${ }^{5}$

By reducing lymphocyte egress from secondary lymphoid organs (SLOs), S1P receptor modulators decrease the peripheral blood absolute lymphocyte count (ALC). ${ }^{5}$ The chemokine receptor CCR7 directs lymphocytes into SLOs, and data suggest that $\mathrm{CCR} 7^{+}$lymphocyte subpopulations are responsive to S1P modulators. ${ }^{6}$ Studies of fingolimod, the first approved S1P receptor modulator and a modulator of receptors $1,3,4$, and $5,^{7-9}$ indicated differential effects on specific $\mathrm{T}$ - and B-cell subtypes. The differential effects of fingolimod on lymphocyte subtypes are being evaluated as possible predictors of clinical response. ${ }^{6,8-11}$ Clinical trials of ozanimod reported expected decreases in $\mathrm{ALCs}^{3,4}$ and differential effects on specific lymphocyte subtypes in healthy volunteers, with $\mathrm{CCR} 7^{+} \mathrm{T}$ cells $\left(\mathrm{CD} 4^{+}, \mathrm{CD}^{+}\right.$, and central memory $\mathrm{T}$ cells) preferentially decreased. ${ }^{12}$

To improve the understanding of the mechanism of action (MOA) of ozanimod in patients with RMS, exploratory analyses from a phase 1 study were conducted to characterize the phenotype of circulating leukocyte subsets in patients with RMS treated with ozanimod using both flow cytometry and epigenetic cell-counting methodologies.

\section{Methods}

\section{Study design}

A phase 1 randomized (1:1), open-label, multiple-dose, parallel-group pharmacodynamic study of ozanimod hydrochloride $(\mathrm{HCl}) 0.5$ or $1 \mathrm{mg} / \mathrm{d}$ (equivalent to ozanimod 0.46 or $0.92 \mathrm{mg}$, respectively) was conducted in participants with RMS at 6 study centers in the United States. Participants were randomized to receive ozanimod $\mathrm{HCl} 0.5$ or $1 \mathrm{mg} / \mathrm{d}$ for approximately 12 weeks, which included an initial 7-day dose escalation consisting of ozanimod $\mathrm{HCl} 0.25 \mathrm{mg} / \mathrm{d}$ (equivalent to ozanimod $0.23 \mathrm{mg}$ ) on days $1-4$ and $0.5 \mathrm{mg} / \mathrm{d}$ on days 5-7. All participants who completed the study were eligible to enter an open-label extension study (DAYBREAK; NCT02576717).

\section{Patients}

Adults aged 18-55 years with RMS, as diagnosed by the revised 2010 McDonald criteria ${ }^{13}$ and exhibiting a relapsing clinical course and a history of brain MRI lesions consistent with RMS, were enrolled. Eligible participants had no history of relapse with onset from 30 days before screening until randomization, were clinically stable during this period without systemic corticosteroid or adrenocorticotropic hormone treatment, and had documentation of positive varicellazoster virus (VZV) immunoglobulin G (IgG) antibody status or complete VZV vaccination at least 30 days before study entry. In addition, they were required to have an Expanded Disability Status Scale score of 0-6 and be generally healthy aside from RMS. Key exclusion criteria included active infection or history of chronic infections or immunodeficiency, recent live vaccination, previous lymphocyte-depleting or immunosuppressant therapy, and ALC $<1.000 \times 10^{9} / \mathrm{L}$ or white blood cell count $<3.500 \times 10^{9} / \mathrm{L}$.

\section{Standard protocol approvals, registrations, and patient consent}

The phase 1 study was approved by an institutional review board and was designed and monitored in compliance with the principles of Good Clinical Practice as required by regulatory authorities and in accordance with the Declaration of Helsinki. All participants provided written informed consent. This study is registered on ClinicalTrials.gov (identifier: NCT02797015).

\section{Data availability}

Celgene, a Bristol-Myers Squibb Company, is committed to responsible and transparent sharing of clinical trial data with patients, health care practitioners, and independent researchers for the purpose of improving scientific and medical knowledge as well as fostering innovative treatment approaches. Data requests may be submitted to Celgene, a Bristol-Myers Squibb Company, at vivli.org/ourmember/celgene/ and must include a description of the research proposal.

\section{Flow cytometry analysis}

As a prespecified pharmacodynamic analysis, the ALC was evaluated on days $1,5,8,28,56$, and 85 (end of treatment). As an exploratory analysis, a flow cytometry panel was used to characterize circulating leukocyte subsets at baseline (day 1 ) and days 28,56 , and 85 . Analyzed subsets included $\mathrm{CD} 19^{+} \mathrm{B}$ cells, $\mathrm{CD}^{+}$ $\mathrm{T}$ cells, monocytes, natural killer $(\mathrm{NK})$ cells, and natural killer $\mathrm{T}$ (NKT) cells, as well as the following T-cell subtypes: $\mathrm{CD}^{+}$and $\mathrm{CD} 8^{+}$central and effector memory $\mathrm{T}$ cells, $\mathrm{CD} 4^{+}$and $\mathrm{CD} 8^{+}$ naive $\mathrm{T}$ cells, and $\mathrm{CD} 8^{+}$terminally differentiated effector $\mathrm{T}$ cells expressing CD45RA (TEMRA). 


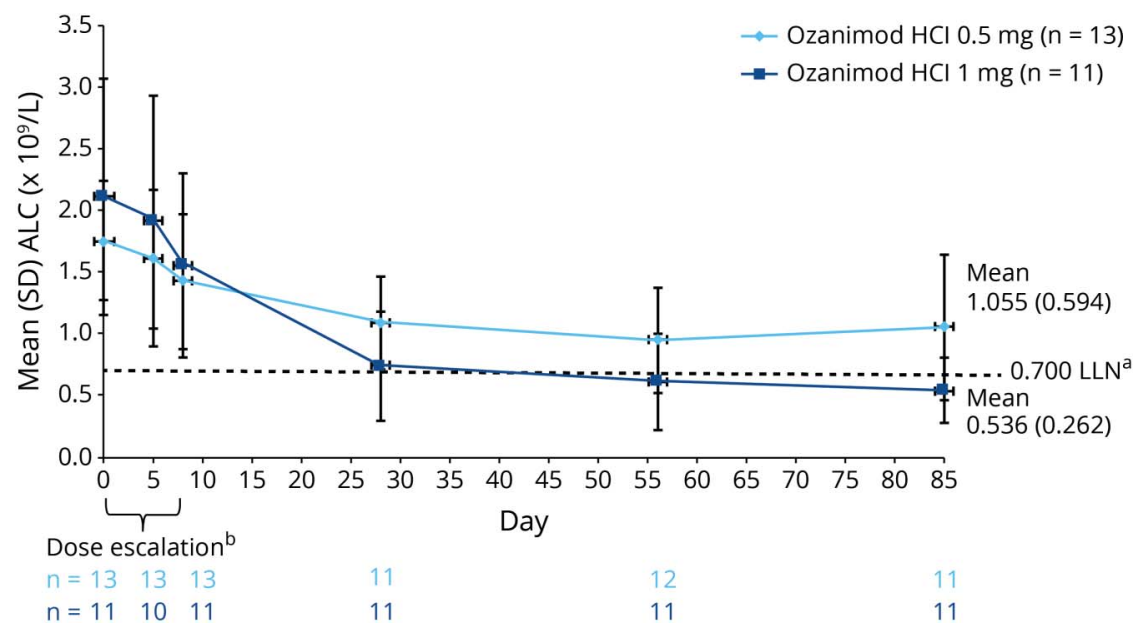

Error bars represent \pm 1 SD. ${ }^{a} L L N$ established by the reference laboratory for the study. ${ }^{\mathrm{b}}$ Dose escalation consisted of ozanimod $\mathrm{HCl} 0.25 \mathrm{mg} / \mathrm{d}$ on days $1-4,0.5 \mathrm{mg} / \mathrm{d}$ on days $5-7$, and then assigned dose $(0.5$ or $1 \mathrm{mg} / \mathrm{d})$ for approximately 12 weeks. $\mathrm{ALC}=$ absolute lymphocyte count; $\mathrm{HCl}=$ hydrochloride; LLN = lower limit of normal; RMS = relapsing MS.
Heparinized whole blood samples were shipped overnight at ambient temperature from clinical sites to the University of California San Francisco, where peripheral blood mononuclear cells were isolated using a standard Ficoll/density gradient centrifugation protocol. Cells were stained for surface antigens with mouse anti-human monoclonal antibodies (CD3, CD4, CD8, CD19, CD20, CD14, CD56, CD16, CD45RA, CD45RO, CCR7, CCR4, CCR6, and CXCR3; BioLegend, San Diego, CA) and LIVE/DEAD Fixable Aqua viability dye (Thermo Fisher Scientific), then fixed and permeabilized using the True-Nuclear Buffer Kit (BioLegend). A single lot of each antibody was used throughout the study, and each sample was tested once. Acquisition was performed on a Becton Dickinson LSRFortessa cell analyzer with FACSDiva software (version 8.0). All data were analyzed using FlowJo version 10.3. A single investigator, who was blinded to the treatment arm, conducted all analyses.

\section{Epigenetic cell-counting analysis}

Epigenetic cell counting was performed by Epiontis/Precision for Medicine, as previously described, ${ }^{14}$ using bisulfiteconverted DNA from frozen whole blood samples as substrate for quantitative PCR assays for selected cell type-specific demethylated loci (table e-1, links.lww.com/NXI/A283). Briefly, $75 \mu \mathrm{L}$ of EDTA-anticoagulated peripheral blood was supplemented with $67 \mu \mathrm{L}$ of lysis buffer comprising $54.25 \mu \mathrm{L}$ of Lysis/Binding Buffer (Invitrogen), $9 \mu \mathrm{L}$ of proteinase $\mathrm{K}$ (Sigma; $30 \mathrm{mg} / \mathrm{mL}$ ), and $3.75 \mu \mathrm{L}$ of GAP [GC] plasmid (to a final concentration of 20,000 copies per $\mu \mathrm{L}$ of whole blood) and lysed for 15 minutes at $56^{\circ} \mathrm{C}$. For conversion, $270 \mu \mathrm{L}$ of $70 \%$ ammonium bisulfite solution was added, and samples were incubated at $80^{\circ} \mathrm{C}$ for 55 minutes. Bisulfite-converted DNA was directly purified using the MyONE Silane genomic DNA kit (Invitrogen) according to the manufacturer's instructions.

Figure 2 Circulating levels of $B$ cells $(A)$ and T cells $(B)$ during ozanimod treatment
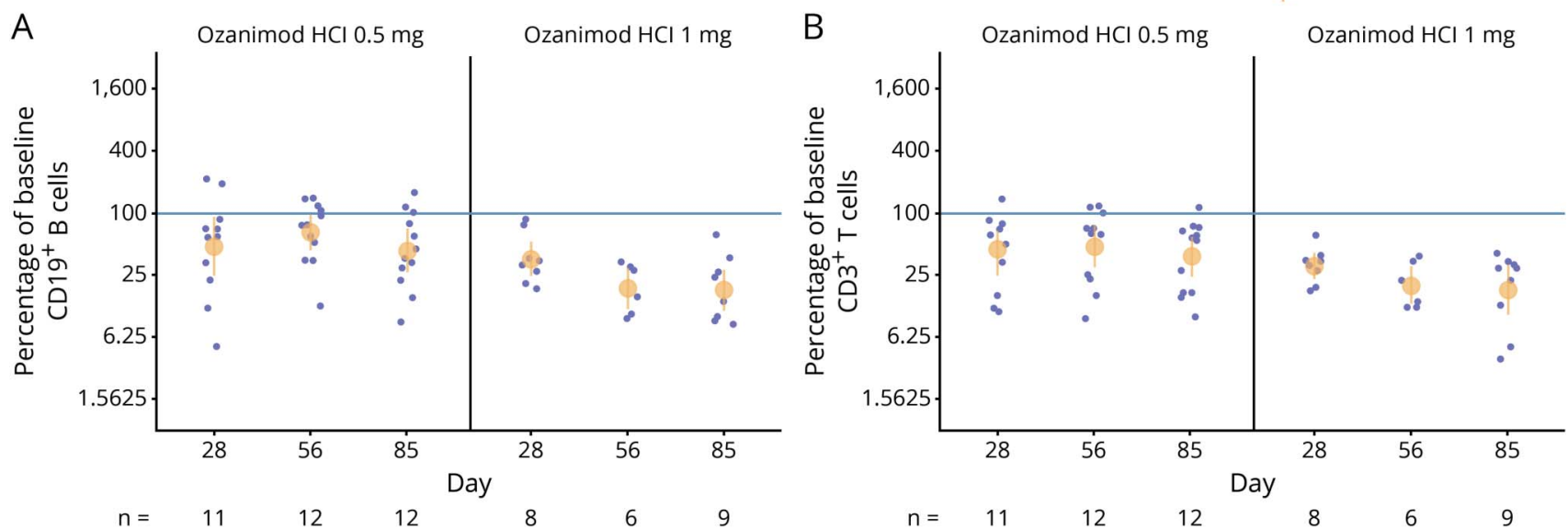

Circulating levels of $\mathrm{CD} 19^{+} \mathrm{B}$ cells and $\mathrm{CD}^{+} \mathrm{T}$ cells were assessed as a percentage of baseline in patients with relapsing MS treated with ozanimod $\mathrm{HCl} 0.5$ or 1 $\mathrm{mg} / \mathrm{d}$, using flow cytometry. $\mathrm{HCl}=$ hydrochloride. 
Table 1 Circulating levels of leukocyte subtypes over time with ozanimod $\mathrm{HCl} 0.5$ or $1 \mathrm{mg} / \mathrm{d}$ expressed as a percentage of baseline cell count, as assessed using flow cytometry

\begin{tabular}{|c|c|c|c|c|c|c|}
\hline Cell type & Ozanimod $\mathrm{HCl} O$ & $5 \mathrm{mg}$ & & Ozanimod $\mathrm{HCl} 1 \mathrm{~m}$ & & \\
\hline $\begin{array}{l}\text { Geometric mean } \\
(95 \% \mathrm{CI}) \% \text { of baseline }\end{array}$ & Day $28(n=11)$ & Day $56(n=12)$ & Day $85(n=12)$ & Day $28(n=8)$ & Day $56(n=6)$ & Day $85(n=9)$ \\
\hline $\mathrm{CD}_{19}{ }^{+} \mathrm{B}$ cells & $46.3(23.8,90.1)$ & $63.9(42.8,95.3)$ & $42.2(25.8,68.9)$ & $34.8(23.5,51.4)$ & $18.0(11.5,28.2)$ & $17.6(11.2,27.6)$ \\
\hline $\mathrm{CD3}^{+} \mathrm{T}$ cells & $44.0(26.4,73.4)$ & $48.9(30.6,78.1)$ & $39.0(24.9,61.2)$ & $31.4(23.8,41.3)$ & $20.4(13.5,30.7)$ & $18.5(10.5,32.5)$ \\
\hline $\mathrm{CD4}^{+} \mathrm{T}$ cells & $39.6(22.7,69.0)$ & $44.9(26.3,76.6)$ & $33.4(19.7,56.5)$ & $26.3(16.8,41.1)$ & $10.2(5.9,17.8)$ & $8.7(4.2,18.1)$ \\
\hline $\mathrm{CD}^{+} \mathrm{T}$ cells & $46.5(26.4,81.9)$ & $47.0(28.6,77.2)$ & $45.4(29.8,69.3)$ & $41.6(31.9,54.3)$ & $36.2(21.7,60.4)$ & $31.9(17.5,58.3)$ \\
\hline $\mathrm{CD4}^{+}$central memory $\mathrm{T}$ cells & $43.6(25.3,75.1)$ & $44.5(26.0,76.1)$ & $37.3(23.7,58.6)$ & $57.6(16.2,205.0)$ & $22.5(6.9,73.6)$ & $17.3(5.3,56.6)$ \\
\hline $\mathrm{CD4}^{+}$effector memory $\mathrm{T}$ cells & $35.0(18.9,64.7)$ & $43.9(23.2,82.9)$ & $31.3(19.6,49.9)$ & $64.5(20.2,206.7)$ & $54.8(17.3,173.8)$ & $36.1(10.3,126.2)$ \\
\hline $\mathrm{CD8}^{+}$central memory $\mathrm{T}$ cells & $41.3(21.0,81.2)$ & $41.9(19.6,89.8)$ & $45.7(28.9,72.2)$ & $43.8(22.2,86.4)$ & $10.1(4.0,25.5)$ & $28.5(13.2,61.8)$ \\
\hline $\mathrm{CD}^{+}$effector memory $\mathrm{T}$ cells & $56.7(32.3,99.7)$ & $62.4(30.9,125.8)$ & $69.1(51.9,92.0)$ & $85.0(54.0,133.7)$ & $70.4(35.1,141.1)$ & $81.8(50.6,132.4)$ \\
\hline $\mathrm{CD4}^{+}$naive $\mathrm{T}$ cells & $33.6(19.8,57.1)$ & $36.0(19.9,65.3)$ & $26.0(13.7,49.5)$ & $37.1(10.1,136.9)$ & $12.6(2.9,54.7)$ & $10.1(2.5,39.9)$ \\
\hline $\mathrm{CD}^{+}$naive $\mathrm{T}$ cells & $30.8(18.5,51.2)$ & $34.6(19.4,61.5)$ & $25.3(13.9,46.0)$ & $16.3(10.6,25.0)$ & $5.4(3.5,8.3)$ & $6.7(2.9,15.0)$ \\
\hline CD8 ${ }^{+}$TEMRA & $\begin{array}{l}53.6 \\
(26.4,108.9)\end{array}$ & $77.4(40.1,149.2)$ & $\begin{array}{l}63.9 \\
(38.2,106.9)\end{array}$ & $95.6(70.4,130.0)$ & $\begin{array}{l}105.2 \\
(62.5,177.1)\end{array}$ & $62.2(20.0,193.7)$ \\
\hline${\mathrm{CD} 14^{+} \text {monocytes }}$ & $\begin{array}{l}114.0 \\
(38.7,335.5)\end{array}$ & $\begin{array}{l}211.0 \\
(108.6,410.1)\end{array}$ & $\begin{array}{l}165.6 \\
(73.9,371.2)\end{array}$ & $\begin{array}{l}222.4 \\
(113.3,436.8)\end{array}$ & $\begin{array}{l}172.7 \\
(83.8,356.3)\end{array}$ & $\begin{array}{l}194.9 \\
(150.0,253.3)\end{array}$ \\
\hline $\mathrm{CD3}^{+} \mathrm{CD}^{-} 6^{+} \mathrm{NKT}$ & $\begin{array}{l}76.7 \\
(38.7,151.8)\end{array}$ & $\begin{array}{l}105.1 \\
(61.0,181.1)\end{array}$ & $\begin{array}{l}87.5 \\
(50.9,150.4)\end{array}$ & $79.8(42.9,148.3)$ & $82.7(58.1,117.6)$ & $65.0(25.6,165.2)$ \\
\hline $\mathrm{CD} 16^{-} \mathrm{CD}^{-} 6^{+} \mathrm{NK}$ & $\begin{array}{l}72.1 \\
(43.4,119.6)\end{array}$ & $87.3(58.4,130.5)$ & $\begin{array}{l}63.3 \\
(33.2,120.7)\end{array}$ & $128.5(77.9,211.9)$ & $\begin{array}{l}101.5 \\
(58.3,176.6)\end{array}$ & $91.4(57.0,146.5)$ \\
\hline $\mathrm{CD}^{-}{ }^{-}$CD56hi NK & $27.1(8.4,83.4)$ & $55.8(27.7,111.3)$ & $24.4(10.9,53.3)$ & $11.5(3.2,36.4)$ & $33.8(21.8,51.9)$ & $16.5(4.4,56.3)$ \\
\hline $\mathrm{CD} 16^{+} \mathrm{CD}^{-} 6^{-} \mathrm{NK}$ & $\begin{array}{l}108.9 \\
(51.6,229.7)\end{array}$ & $\begin{array}{l}138.9 \\
(69.9,276.2)\end{array}$ & $\begin{array}{l}151.7 \\
(62.4,369.0)\end{array}$ & $\begin{array}{l}418.8 \\
(164.1,1069.2)\end{array}$ & $\begin{array}{l}344.0 \\
(186.5,634.6)\end{array}$ & $\begin{array}{l}303.5 \\
(158.3,581.8)\end{array}$ \\
\hline $\mathrm{CD}_{16}{ }^{+} \mathrm{CD} 56^{+} \mathrm{NK}$ & $\begin{array}{l}80.5 \\
(33.4,193.9)\end{array}$ & $\begin{array}{l}154.2 \\
(96.4,246.5)\end{array}$ & $\begin{array}{l}114.4 \\
(70.9,184.5)\end{array}$ & $91.6(40.1,209.2)$ & $\begin{array}{l}159.1 \\
(117.5,215.4)\end{array}$ & $94.7(43.4,206.8)$ \\
\hline CD16 ${ }^{+}$CD56hi NK & $30.9(7.6,117.4)$ & $72.8(37.2,141.2)$ & $25.9(9.8,66.4)$ & $20.5(5.8,66.6)$ & $62.0(36.4,105.1)$ & $20.3(5.0,74.8)$ \\
\hline
\end{tabular}

Abbreviations: $\mathrm{HCl}=$ hydrochloride; $\mathrm{n}$ = number of observed values; $\mathrm{NK}=$ natural killer cells; NKT = natural killer T cells; TEMRA = terminally differentiated effector T cells expressing CD45RA.

Where the data contained values of 0,1 was added to all values before log transformation and subtracted when converting back to the original scale. Percentage of baseline for $\mathrm{CD}^{+}$and $\mathrm{CD}^{+}$cells is based on $\%$ of $\mathrm{CD}^{+} \mathrm{T}$ cells.

Bisulfite conversion rates were analyzed previously and are provided in the manufacturer's manual with values above $98 \%$. Thermal cycling was performed as follows: $1 \times 95^{\circ} \mathrm{C}$ for 35 minutes, followed by $50 \times 95^{\circ} \mathrm{C}$ for 15 seconds, and $61^{\circ} \mathrm{C}$ for 1 minute in $10 \mu \mathrm{L}$ using the Roche LightCycler 480 Probes Master. For the calculation of cell numbers from autosomal genes, a 2:1 allele-to-cell ratio was assumed. ${ }^{14}$

\section{Statistical analysis}

This was a clinical pharmacology study without formal hypothesis testing. A sample size of approximately 12 subjects per dose group was deemed adequate to characterize the pharmacodynamics of ozanimod. ALC, flow cytometry, and epigenetic cell-counting data were summarized using the number of observed (nonmissing) observations, without imputation; however, patients with a missing baseline (day 1) ALC value used the ALC value from the screening visit as their baseline
ALC. Circulating leukocyte subset counts were compared with baseline (day 1) using descriptive statistics. The geometric mean, used to report a percentage of the baseline cell count, is the mean of the logged values, then transformed back to the original scale; the $95 \%$ CIs were likewise computed on the log scale and then transformed back. All analyses were performed using $\mathrm{R}$ version 3.6.1 (2019-07-05) (R Core Team 2018).

\section{Results}

\section{Patients}

A total of 24 participants were randomized to ozanimod $\mathrm{HCl}$ $0.5 \mathrm{mg}(\mathrm{n}=13)$ or $1 \mathrm{mg}(\mathrm{n}=11)$; the mean $(\mathrm{SD})$ age was 38.8 (8.4) years. Participants were predominantly women $(70.8 \%)$ and White (75.0\%; 5 participants [20.8\%] were Black and 1 [4.2\%] was Asian). All participants completed treatment, 
Figure 3 Flow cytometry analysis of circulating levels of central vs effector memory T cells
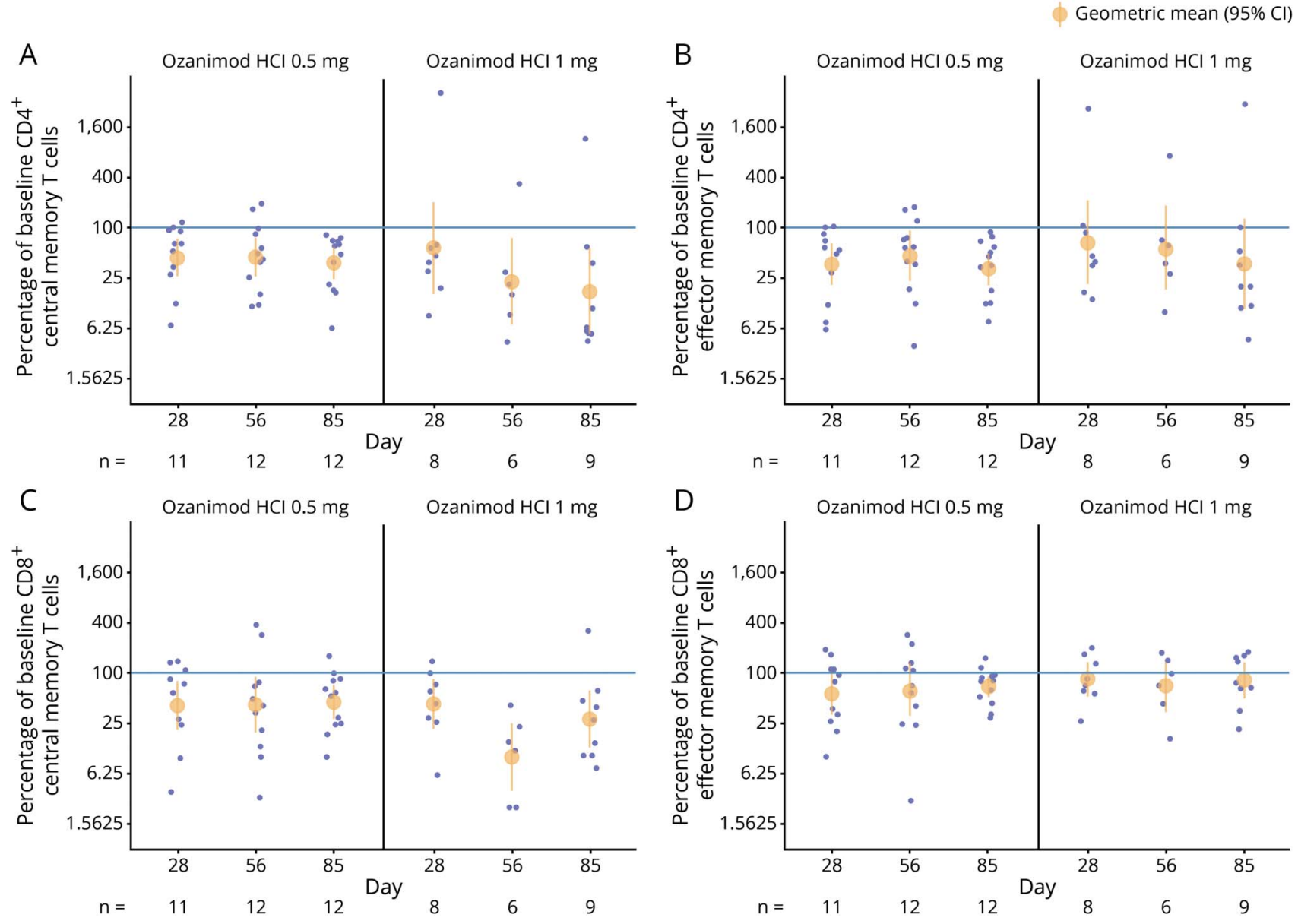

Circulating levels of (A) CD4 $4^{+}$central memory T cells, (B) CD4 $4^{+}$effector memory T cells, (C) CD8 ${ }^{+}$central memory T cells, and (D) CD8 ${ }^{+}$effector memory T cells during treatment with ozanimod $\mathrm{HCl} 0.5$ or $1 \mathrm{mg} / \mathrm{d}$, as assessed using flow cytometry. $\mathrm{HCl}=$ hydrochloride.

except 1 participant in the ozanimod $\mathrm{HCl} 0.5 \mathrm{mg}$ group who withdrew from the study after day 8 (figure e-1, links.lww.com/ NXI/A282). The first participant enrolled on July 21, 2016, and the last participant completed the study on October 20, 2017.

\section{Course of ALC}

The mean (SD) ALC at baseline was $1.754(0.489) \times 10^{9} / \mathrm{L}$ in the ozanimod $\mathrm{HCl} 0.5 \mathrm{mg}$ group and $2.118(0.961) \times 10^{9} / \mathrm{L}$ in the ozanimod $\mathrm{HCl} 1 \mathrm{mg}$ group. After dose escalation, ozanimod was associated with dose-dependent reductions in ALCs (figure 1). At the end of treatment (day 85), the mean (SD) ALC was $1.055(0.594) \times 10^{9} / \mathrm{L}(42.2 \%$ reduction from baseline) in the ozanimod $\mathrm{HCl} 0.5 \mathrm{mg}$ group and 0.536 $(0.262) \times 10^{9} / \mathrm{L}(73.3 \%$ reduction from baseline $)$ in the ozanimod $\mathrm{HCl} 1 \mathrm{mg}$ group.

\section{Effect of ozanimod on circulating leukocyte subsets}

\section{Flow cytometry analysis}

Flow cytometry analysis of circulating leukocyte subsets indicated that the dose-dependent decreases in ALCs with ozanimod treatment were primarily due to decreases in circulating $\mathrm{CD} 19^{+} \mathrm{B}$ cells and $\mathrm{CD}^{+} \mathrm{T}$ cells (figure 2, $\mathrm{A}$ and $\mathrm{B}$; table 1). There were minimal to no decreases in monocytes, NK, and NKT cells (table 1).

Further analysis of specific T-cell subtypes revealed greater decreases in $\mathrm{CD}^{+}{ }^{+} \mathrm{T}$-helper cells than $\mathrm{CD} 8^{+}$cytotoxic $\mathrm{T}$ cells in the ozanimod $\mathrm{HCl} 1 \mathrm{mg}$ group (table 1), as well as greater decreases in both $\mathrm{CD} 4^{+}$and $\mathrm{CD} 8^{+}$central memory $\mathrm{T}$ cells vs effector memory $\mathrm{T}$ cells (figure 3 and table 1 ). By the end of treatment, ozanimod $\mathrm{HCl} 1 \mathrm{mg}$ reduced mean $\mathrm{CD} 4^{+}$and $\mathrm{CD}^{+}$naive $\mathrm{T}$ cells by $\geq 90 \%$; ozanimod did not reduce circulating $\mathrm{CD}^{+}$TEMRA (table 1).

\section{Epigenetic cell-counting analysis}

In the epigenetic cell-counting analysis, total circulating leukocytes at day 85 were reduced to $90 \%$ (95\% CI: 78\%, 104\%) and $73 \%$ (95\% CI: 55\%, 97\%) of baseline in the ozanimod $\mathrm{HCl} 0.5$ and $1 \mathrm{mg}$ groups, respectively. Results for specific leukocyte subsets were consistent with the flow cytometry results in showing dose-dependent decreases in total circulating B cells and T cells with ozanimod treatment, as well as 


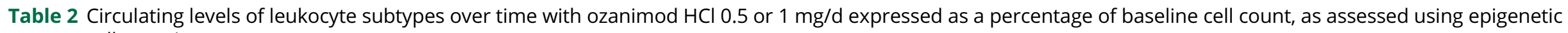
cell counting

\begin{tabular}{|c|c|c|c|c|c|c|c|c|c|c|}
\hline \multirow[b]{2}{*}{ Cell type } & \multicolumn{5}{|c|}{ Ozanimod HCl 0.5 mg } & \multicolumn{5}{|c|}{ Ozanimod HCl 1 mg } \\
\hline & Day 2 & Day 5 & Day 28 & Day 56 & Day 85 & Day 2 & Day 5 & Day 28 & Day 56 & Day 85 \\
\hline CD19 ${ }^{+}$B cells, $n$ & 11 & 13 & 12 & 12 & 10 & 11 & 10 & 11 & 10 & 10 \\
\hline Gmean $(95 \% \mathrm{Cl})$ & $84.7(75.8,94.5)$ & $76.6(66.4,88.3)$ & $45.1(34.7,58.6)$ & $40.8(32.8,50.7)$ & $38.2(25.9,56.4)$ & $89.4(76.8,104.2)$ & $79.5(69.6,90.8)$ & $24.6(20.4,29.7)$ & $19.3(15.4,24.1)$ & $17.0(14.2,20.2)$ \\
\hline $\mathrm{CD}^{+} \mathrm{T}$ cells, $\mathrm{n}$ & 6 & 8 & 8 & 8 & 8 & 4 & 3 & 4 & 4 & 4 \\
\hline Gmean $(95 \% \mathrm{Cl})$ & $84.0(74.8,94.5)$ & $74.5(61.4,90.5)$ & $50.5(39.3,64.8)$ & $32.2(20.7,49.9)$ & $34.6(20.1,59.5)$ & $96.2(79.8,116.1)$ & $90.6(82.3,99.9)$ & $19.4(11.1,33.8)$ & $12.1(5.6,26.0)$ & $10.6(6.2,18.3)$ \\
\hline $\mathrm{CD}^{+} \mathrm{T}$ cells, $\mathrm{n}$ & 10 & 13 & 12 & 12 & 11 & 11 & 10 & 11 & 11 & 11 \\
\hline Gmean $(95 \% \mathrm{Cl})$ & $86.1(76.2,97.4)$ & $84.3(73.2,97.1)$ & $63.4(54.7,73.4)$ & $44.1(36.3,53.5)$ & $46.1(32.5,65.5)$ & $97.4(84.9,111.9)$ & $96.6(84.2,110.7)$ & $26.7(21.5,33.2)$ & $21.4(16.9,27.0)$ & $22.5(18.8,27.1)$ \\
\hline CD8 $^{+} T$ cells, $n$ & 11 & 13 & 12 & 12 & 11 & 11 & 10 & 10 & 10 & 10 \\
\hline Gmean $(95 \% \mathrm{Cl})$ & $89.9(76.9,105.2)$ & $79.0(68.5,91.1)$ & $53.1(45.5,62.1)$ & $43.4(34.1,55.3)$ & $39.3(29.1,53.0)$ & $91.5(79.3,105.6)$ & $88.5(79.5,98.5)$ & $32.2(23.3,44.6)$ & $28.8(20.3,40.9)$ & $24.5(18.2,33.0)$ \\
\hline $\begin{array}{l}\text { CD8 }{ }^{+} \text {naive } \\
T \text { cells, } n\end{array}$ & 5 & 5 & 4 & 4 & 3 & 7 & 7 & 7 & 7 & 7 \\
\hline Gmean $(95 \% \mathrm{Cl})$ & $79.8(60.6,105.0)$ & $92.7(75.7,113.5)$ & $45.2(26.1,78.5)$ & $37.5(25.3,55.8)$ & $38.4(34.3,42.9)$ & $78.3(64.1,95.7)$ & $78.9(68.3,91.3)$ & $18.5(12.9,26.7)$ & $16.2(7.9,33.1)$ & $12.6(7.3,21.6)$ \\
\hline Th17 cells, $n$ & 11 & 13 & 12 & 12 & 11 & 11 & 10 & 11 & 11 & 11 \\
\hline Gmean $(95 \% \mathrm{Cl})$ & $88.2(80.3,96.9)$ & $89.0(78.7,100.6)$ & $51.6(43.5,61.2)$ & $38.1(28.2,51.5)$ & $38.0(25.9,55.8)$ & $94.7(81.9,109.5)$ & $87.1(76.6,98.9)$ & $20.2(15.4,26.5)$ & $13.7(9.9,18.9)$ & $11.5(8.6,15.4)$ \\
\hline Treg cells, $n$ & 6 & 8 & 6 & 6 & 7 & 4 & 3 & 3 & 3 & 2 \\
\hline Gmean $(95 \% \mathrm{Cl})$ & $98.2(79.0,122.0)$ & $74.9(61.3,91.6)$ & $62.3(50.2,77.3)$ & $54.3(41.7,70.9)$ & $51.7(36.0,74.4)$ & $103.9(91.5,118.0)$ & $86.9(61.8,122.3)$ & $45.7(18.7,111.4)$ & $35.3(21.9,57.1)$ & $34.6(14.5,82.6)$ \\
\hline PD-1 ${ }^{+}$cells, $n$ & 5 & 5 & 4 & 4 & 3 & 7 & 7 & 7 & 7 & 7 \\
\hline Gmean $(95 \% \mathrm{Cl})$ & $86.8(65.5,115.1)$ & $98.2(70.1,137.6)$ & $57.7(36.8,90.3)$ & $62.9(49.5,79.8)$ & $76.2(45.4,128.0)$ & $78.3(64.8,94.7)$ & $81.0(71.2,92.3)$ & $35.3(26.0,47.9)$ & $35.2(25.8,47.9)$ & $34.2(26.5,44.3)$ \\
\hline
\end{tabular}

Abbreviations: Gmean = geometric mean; $\mathrm{HCl}=$ hydrochloride; $\mathrm{n}=$ number of observed values; $\mathrm{PD}-1^{+}=$programmed cell death 1 . 

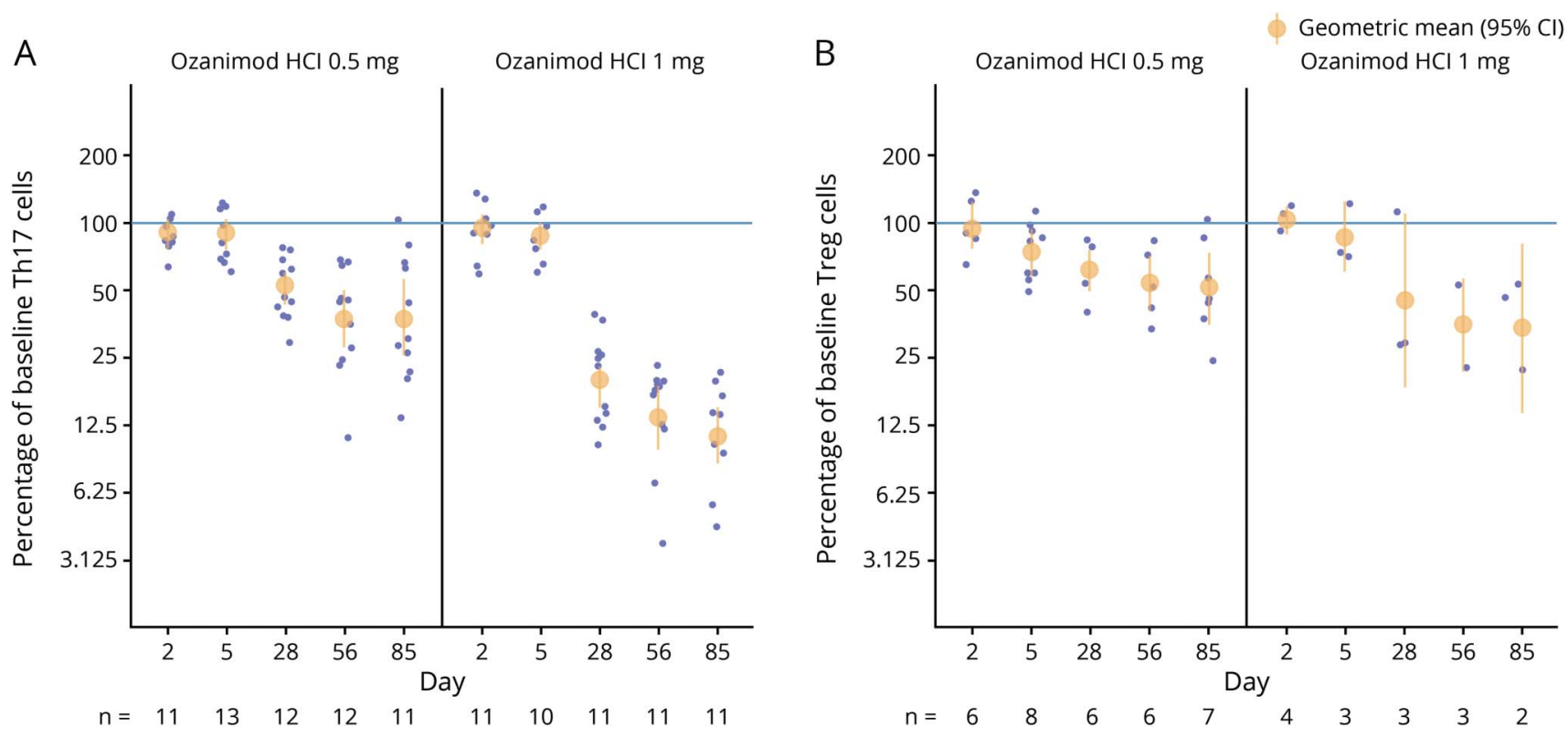

Circulating levels of (A) Th17 cells and (B) Treg cells during treatment with ozanimod $\mathrm{HCl} 0.5$ or $1 \mathrm{mg} / \mathrm{d}$, as assessed using epigenetic cell counting. $\mathrm{HCl}=$ hydrochloride.

decreases in $\mathrm{CD}^{+} \mathrm{T}$-helper and $\mathrm{CD} 8^{+}$cytotoxic $\mathrm{T}$ cells and naive $\mathrm{CD} 8^{+} \mathrm{T}$ cells (table 2). This analysis also demonstrated greater reductions in Th17 cells than T regulatory (Treg) cells or programmed cell death $1(\mathrm{PD}-1)^{+}$cells (figure 4 and table 2).

\section{Discussion}

These data represent the first reported analyses of the effect of ozanimod on leukocyte subsets in patients with RMS. In addition to flow cytometry, a novel epigenetic cell-counting method was used, and both methodologies support the MOA of ozanimod and differential effects on peripheral blood leukocyte subsets. Specifically, this phase 1 study confirmed that treatment with ozanimod produced dose-dependent reductions in ALCs over 12 weeks in patients with RMS. Results from the exploratory analyses demonstrated that this reduction was due primarily to decreases in $\mathrm{T}$ and $\mathrm{B}$ cells. In the flow cytometry analysis, the greatest $\mathrm{T}$-cell reductions were seen in $\mathrm{CD}^{+}$naive and central memory subsets, whereas $\mathrm{CD} 8^{+}$effector memory $\mathrm{T}$ cells and TEMRA were not reduced from baseline (table 1). This profile is consistent with the expected effects of $\mathrm{S}_{1} \mathrm{P}_{1}$ receptor modulation, given the link between chemokine receptor CCR7 expression and $\mathrm{S}_{1} \mathrm{P}_{1}$ receptormediated egress of lymphocytes from lymph nodes; CCR7 is expressed on B cells and both naive and central memory $\mathrm{T}$ cells, but not on effector memory $\mathrm{T}$ cells or TEMRA. ${ }^{9}$ The differential effects on $\mathrm{CCR}^{+}$lymphocyte subsets observed in the current study are in agreement with those reported previously with ozanimod in healthy volunteers. ${ }^{12}$ Moreover, this profile mirrors patterns of lymphocyte effects reported with fingolimod in patients with MS and with siponimod ${ }^{15}$ and ponesimod ${ }^{16,17}$ in healthy volunteers.

Our flow cytometry analysis further demonstrated that ozanimod had a minimal effect on circulating levels of other leukocyte subtypes, including NK and NKT cells and monocytes, suggesting a differential effect of treatment on specific leukocyte subpopulations. This has potential clinical implications, given the role of these subtypes in the innate immune response necessary for immunosurveillance against infections and tumors. ${ }^{18-20}$ One of the concerns surrounding the use of immunomodulatory therapies is the potential for increased risks of infection and malignancy. However, phase 3 clinical trials of ozanimod showed infection rates that were comparable with patients treated with IM interferon beta-1a, and infrequent serious infections, no serious opportunistic infections, and low $(<1 \%)$ rates of malignancy among patients with RMS receiving ozanimod. ${ }^{3,4}$

Our flow cytometry results were further supported by results from a second analysis based on epigenetic cell counting, a recently developed method of immune cell quantification. This method provides relative and absolute immune cell counts based on PCR amplification and quantification of cell type-specific DNA methylation markers. ${ }^{14,21,22}$ In a previous analysis, results from epigenetic cell counting were found to correlate highly (Spearman rank correlation coefficients of $0.96-0.98, p<0.001)$ with flow cytometry results in both healthy controls and HIV+ individuals for all cell types studied. ${ }^{14}$ Although correlations could not be meaningfully estimated in our analysis due to small sample sizes and missing data, results from the epigenetic cell-counting analysis were generally consistent with flow cytometry results for the 
leukocyte subtypes analyzed by both methods, specifically substantial decreases in $\mathrm{B}$ and $\mathrm{T}$ cells, including $\mathrm{CD} 4^{+}$and $\mathrm{CD}^{+}{ }^{+} \mathrm{T}$ cells and $\mathrm{CD} 8^{+}$naive $\mathrm{T}$ cells (tables 1 and 2). Epigenetic cell-counting results also demonstrated that ozanimod is associated with greater reductions in proinflammatory Th17 cells ${ }^{23}$ compared with Treg cells. This has potential clinical implications in that Th17/Treg balance is believed to be an important factor in MS disease activity. ${ }^{24-27}$ Interestingly, a small study assessing circulating levels of Th17 and Treg after fingolimod initiation for RMS reported variable effects on Th17 levels, in which 11 of 21 (52.4\%) patients showed an increased proportion of Th17 cells after 4 weeks of treatment, and increased levels of Th17 cells were associated with MS relapses after fingolimod initiation. ${ }^{28}$

Finally, these analyses confirmed the dose-dependent effects of ozanimod on circulating levels of leukocyte subtypes, in which ozanimod $\mathrm{HCl} 1 \mathrm{mg}$ clearly produced greater reductions in $\mathrm{T}$ and B cells than ozanimod $\mathrm{HCl} 0.5 \mathrm{mg}$. This dose dependence can be seen in both flow cytometry and epigenetic cell-counting results. In addition, these cell counts showed continued decreases over time in the ozanimod $\mathrm{HCl} 1 \mathrm{mg}$ group, whereas a time-dependent effect was less evident with the ozanimod $\mathrm{HCl}$ $0.5 \mathrm{mg}$ group. These dose-related effects on cell counts are consistent with the dose-related clinical findings from the phase 3 RMS studies, in which ozanimod $\mathrm{HCl} 1 \mathrm{mg}$ achieved a numerically lower annualized relapse rate and fewer brain MRI lesions compared with ozanimod $\mathrm{HCl} 0.5 \mathrm{mg}$.

Although providing valuable information for the more detailed understanding of the MOA of ozanimod and avenues for further research, the analyses reported here were exploratory in nature. The phase 1 study forming the basis of these analyses enrolled a small number of patients $(\mathrm{N}=24)$, and even smaller numbers of samples were available for analysis for some of the subtypes. Owing to differences in the data sets, no formal statistical comparisons correlating results from flow cytometry vs epigenetic cell counting were made. Nevertheless, consistency in results between the 2 methods suggests the utility of the newer epigenetic cell-counting methodology and provides greater confidence in the overall cell typespecific effects of ozanimod treatment. This observation suggests that a cross-validation study of epigenetic cellcounting and flow cytometry methods could be pursued.

These analyses support that, in line with its MOA, ozanimod produced dose-dependent reductions in B- and T-cell counts in peripheral blood of patients with RMS. A differential effect of ozanimod on specific leukocyte subtypes in patients with RMS was observed.

\section{Acknowledgment}

The authors thank Epiontis/Precision for Medicine for conducting the epigenetic cell counting. Under guidance from the authors, support for this manuscript was provided by Marci Mikesell (help with drafting the manuscript), Jennifer Fernandez, PhD, and Jessica Herr, PharmD (editing the manuscript), and Lorraine Sweeney (proofreading), of Peloton Advantage, LLC, an OPEN Health company, and funded by Bristol-Myers Squibb Company.

\section{Study funding}

This study was sponsored by Celgene Corporation.

\section{Disclosure}

S. Harris and J.Q. Tran are employees of Bristol-Myers Squibb Company. H. Southworth received compensation from Aptus Clinical, BresMed Health Solutions, Celgene, CytomX, F2G, GlaxoSmithKline, and Gossamer Bio. C.M. Spencer reports no disclosures. B.A.C. Cree received personal compensation from Akili, Alexion, Atara, Biogen, EMD Serono, Novartis, and TG Therapeutics. S.S. Zamvil served on data safety monitoring boards of Opexa, BioMS, Teva, and Eli Lilly; is a member of the clinical advisory board of the Myelin Repair Foundation; received speaker honoraria from Biogen and Teva; is a deputy editor of Neurology ${ }^{\oplus}$ Neuroimmunology \& Neuroinflammation; consulted for Biogen, Teva, EMD Serono, Genzyme, Novartis, and Roche; serves on the speaker's bureau of Advanced Health Media and Biogen; and received research support from Biogen, Teva, the NIH, the NMSS, the Weill Institute, and Alexander M. and June L. Maisin Foundation. Go to Neurology.org/NN for full disclosures.

\section{Publication history}

Received by Neurology: Neuroimmunology \& Neuroinflammation March 13, 2020. Accepted in final form June 17, 2020.

Appendix Authors

\begin{tabular}{lll}
\hline Name & Location & Contribution \\
\hline $\begin{array}{l}\text { Sarah Harris, } \\
\text { PhD }\end{array}$ & $\begin{array}{l}\text { Bristol-Myers Squibb } \\
\text { Company, Princeton, NJ }\end{array}$ & $\begin{array}{l}\text { Interpretation of the data } \\
\text { and revised the } \\
\text { manuscript for intellectual } \\
\text { content }\end{array}$ \\
\hline
\end{tabular}

Jonathan Q. Bristol-Myers Squibb Design of the clinical study
Tran, $\quad$ Company, Princeton, NJ, at interpretation of the data, PharmD the time this study was and revised the conducted manuscript for intellectual content

\begin{tabular}{|c|c|c|}
\hline $\begin{array}{l}\text { Harry } \\
\text { Southworth, } \\
\text { PhD, MSc }\end{array}$ & $\begin{array}{l}\text { Data Clarity Consulting } \\
\text { Ltd, Stockport, England, } \\
\text { United Kingdom }\end{array}$ & $\begin{array}{l}\text { Analysis of the data and } \\
\text { revised the manuscript for } \\
\text { intellectual content }\end{array}$ \\
\hline $\begin{array}{l}\text { Collin M. } \\
\text { Spencer, BS }\end{array}$ & $\begin{array}{l}\text { Department of Neurology, } \\
\text { Weill Institute for } \\
\text { Neurosciences, and } \\
\text { Program in Immunology } \\
\text { UCSF, San Francisco, CA }\end{array}$ & $\begin{array}{l}\text { Design of the flow } \\
\text { cytometry study, } \\
\text { acquisition and analysis of } \\
\text { the data, and participated } \\
\text { in writing the manuscript }\end{array}$ \\
\hline $\begin{array}{l}\text { Bruce A. C. } \\
\text { Cree, MD, } \\
\text { PhD, MAS }\end{array}$ & $\begin{array}{l}\text { Department of Neurology, } \\
\text { Weill Institute for } \\
\text { Neurosciences, UCSF, } \\
\text { San Francisco, CA }\end{array}$ & $\begin{array}{l}\text { Design of the flow } \\
\text { cytometry study, } \\
\text { acquisition of the data, } \\
\text { interpretation of the data, } \\
\text { and participated in writing } \\
\text { the manuscript }\end{array}$ \\
\hline $\begin{array}{l}\text { Scott S. } \\
\text { Zamvil, MD, } \\
\text { PhD }\end{array}$ & $\begin{array}{l}\text { Department of Neurology, } \\
\text { Weill Institute for } \\
\text { Neurosciences, and } \\
\text { Program in Immunology } \\
\text { UCSF, San Francisco, CA }\end{array}$ & $\begin{array}{l}\text { Design of the flow } \\
\text { cytometry study, } \\
\text { interpretation of the data, } \\
\text { and participated in writing } \\
\text { the manuscript }\end{array}$ \\
\hline
\end{tabular}




\section{References}

1. Cohen JA, Arnold DL, Comi G, et al. Safety and efficacy of the selective sphingosine 1-phosphate receptor modulator ozanimod in relapsing multiple sclerosis (RADIANCE): a randomised, placebo-controlled, phase 2 trial. Lancet Neurol 2016;15:373-381.

2. Cohen JA, Comi G, Arnold DL, et al. Efficacy and safety of ozanimod in multiple sclerosis: dose-blinded extension of a randomized phase II study. Mult Scler 2019;25: $1255-1262$.

3. Cohen JA, Comi G, Selmaj KW, et al. Safety and efficacy of ozanimod versus interferon beta-1a in relapsing multiple sclerosis (RADIANCE): a multicentre, randomised, 24-month, phase 3 trial. Lancet Neurol 2019;18:1021-1033.

4. Comi G, Kappos L, Selmaj KW, et al. Safety and efficacy of ozanimod versus interferon beta-1a in relapsing multiple sclerosis (SUNBEAM): a multicentre, randomised, minimum 12-month, phase 3 trial. Lancet Neurol 2019;18:1009-1020.

5. Scott FL, Clemons B, Brooks J, et al. Ozanimod (RPC1063) is a potent sphingosine1-phosphate receptor-1 (S1P1) and receptor-5 (S1P5) agonist with autoimmune disease-modifying activity. Br J Pharmacol 2016;173:1778-1792.

6. Mehling M, Brinkmann V, Antel J, et al. FTY720 therapy exerts differential effects on T cell subsets in multiple sclerosis. Neurology 2008;71:1261-1267.

7. Mandala S, Hajdu R, Bergstrom J, et al. Alteration of lymphocyte trafficking by sphingosine-1-phosphate receptor agonists. Science 2002;296:346-349.

8. Muls N, Dang HA, Sindic CJ, van Pesch V. Fingolimod increases CD39-expressing regulatory $\mathrm{T}$ cells in multiple sclerosis patients. PLoS One 2014;9:e113025.

9. Teniente-Serra A, Hervas JV, Quirant-Sanchez B, et al. Baseline differences in minor lymphocyte subpopulations may predict response to fingolimod in relapsingremitting multiple sclerosis patients. CNS Neurosci Ther 2016;22:584-592.

10. Quirant-Sanchez B, Hervas-Garcia JV, Teniente-Serra A, et al. Predicting therapeutic response to fingolimod treatment in multiple sclerosis patients. CNS Neurosci Ther 2018;24:1175-1184.

11. Kaufmann M, Haase R, Proschmann U, Ziemssen T, Akgun K. Real world lab data: patterns of lymphocyte counts in fingolimod treated patients. Front Immunol 2018;9: 2669.

12. Tran JQ, Hartung JP, Peach RJ, et al. Results from the first-in-human study with ozanimod, a novel, selective sphingosine-1-phosphate receptor modulator. J Clin Pharmacol 2017;57:988-996.

13. Polman $\mathrm{CH}$, Reingold SC, Banwell B, et al. Diagnostic criteria for multiple sclerosis: 2010 revisions to the McDonald criteria. Ann Neurol 2011;69:292-302.
14. Baron U, Werner J, Schildknecht $\mathrm{K}$, et al. Epigenetic immune cell counting in human blood samples for immunodiagnostics. Sci Transl Med 2018;10:eaan3508.

15. Gergely P, Nuesslein-Hildesheim B, Guerini D, et al. The selective sphingosine 1-phosphate receptor modulator BAF312 redirects lymphocyte distribution and has species-specific effects on heart rate. Br J Pharmacol 2012;167:1035-1047.

16. D'Ambrosio D, Steinmann J, Brossard P, Dingemanse J. Differential effects of ponesimod, a selective S1P1 receptor modulator, on blood-circulating human T cell subpopulations. Immunopharmacol Immunotoxicol 2015;37:103-109.

17. Jurcevic S, Juif PE, Hamid C, Greenlaw R, D'Ambrosio D, Dingemanse J. Effects of multiple-dose ponesimod, a selective S1P1 receptor modulator, on lymphocyte subsets in healthy humans. Drug Des Devel Ther 2017;11:123-131.

18. Kaur G, Trowsdale J, Fugger L. Natural killer cells and their receptors in multiple sclerosis. Brain 2013;136:2657-2676.

19. Wolf BJ, Choi JE, Exley MA. Novel approaches to exploiting invariant NKT cells in cancer immunotherapy. Front Immunol 2018;9:384.

20. Abel AM, Yang C, Thakar MS, Malarkannan S. Natural killer cells: development, maturation, and clinical utilization. Front Immunol 2018;9:1869.

21. Wieczorek G, Asemissen A, Model F, et al. Quantitative DNA methylation analysis of FOXP3 as a new method for counting regulatory $\mathrm{T}$ cells in peripheral blood and solid tissue. Cancer Res 2009;69:599-608.

22. Singh A, Yamamoto M, Ruan J, et al. Th17/Treg ratio derived using DNA methylation analysis is associated with the late phase asthmatic response. Allergy Asthma Clin Immunol 2014;10:32.

23. Gonzalez H, Pacheco R. T-cell-mediated regulation of neuroinflammation involved in neurodegenerative diseases. J Neuroinflammation 2014;11:201.

24. Shen H, Bonner JA, Shi LZ. Metabolic checkpoints in neurodegenerative T helper 17 (TH17) and neuroregenerative regulatory $\mathrm{T}$ (Treg) cells as new therapeutic targets for multiple sclerosis. Neural Regen Res 2020;15:267-269.

25. Rostami A, Ciric B. Role of Th17 cells in the pathogenesis of CNS inflammatory demyelination. J Neurol Sci 2013;333:76-87.

26. Brucklacher-Waldert V, Stuerner K, Kolster M, Wolthausen J, Tolosa E. Phenotypical and functional characterization of T helper 17 cells in multiple sclerosis. Brain 2009;132:3329-3341.

27. Liu J, Mori M, Sugimoto K, et al. Peripheral blood helper $\mathrm{T}$ cell profiles and their clinical relevance in MOG-IgG-associated and AQP4-IgG-associated disorders and MS. J Neurol Neurosurg Psychiatry 2020;91:132-139.

28. Sato DK, Nakashima I, Bar-Or A, et al. Changes in Th17 and regulatory T cells after fingolimod initiation to treat multiple sclerosis. J Neuroimmunol 2014;268:95-98. 


\section{Neurology $^{\odot}$ \\ Neuroimmunology \& Neuroinflammation}

\section{Effect of the sphingosine-1-phosphate receptor modulator ozanimod on leukocyte subtypes in relapsing MS \\ Sarah Harris, Jonathan Q. Tran, Harry Southworth, et al. \\ Neurol Neuroimmunol Neuroinflamm 2020;7; \\ DOI 10.1212/NXI.0000000000000839}

This information is current as of July 31, 2020

\section{Updated Information \& \\ Services}

References

Citations

Subspecialty Collections

Permissions \& Licensing

Reprints including high resolution figures, can be found at:

http://nn.neurology.org/content/7/5/e839.full.html

This article cites 28 articles, 4 of which you can access for free at: http://nn.neurology.org/content/7/5/e839.full.html\#\#ref-list-1

This article has been cited by 1 HighWire-hosted articles: http://nn.neurology.org/content/7/5/e839.full.html\#\#otherarticles

This article, along with others on similar topics, appears in the following collection(s):

All Neuropsychology/Behavior

http://nn.neurology.org//cgi/collection/all_neuropsychology_behavior

Information about reproducing this article in parts (figures,tables) or in its entirety can be found online at:

http://nn.neurology.org/misc/about.xhtml\#permissions

Information about ordering reprints can be found online:

http://nn.neurology.org/misc/addir.xhtml\#reprintsus

Neurol Neuroimmunol Neuroinflamm is an official journal of the American Academy of Neurology.

Published since April 2014, it is an open-access, online-only, continuous publication journal. Copyright

Copyright $\odot 2020$ The Author(s). Published by Wolters Kluwer Health, Inc. on behalf of the American

Academy of Neurology.. All rights reserved. Online ISSN: 2332-7812.

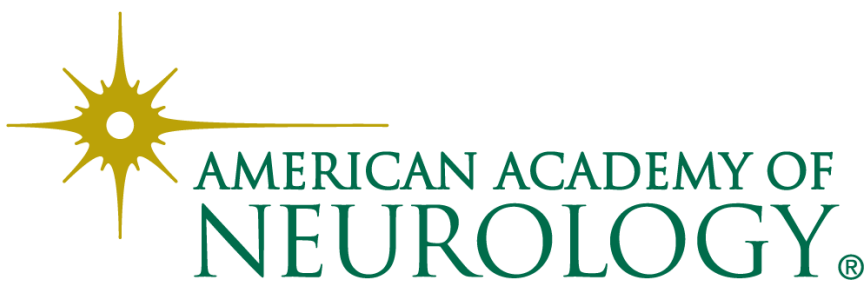

